\title{
Economics, Academics and Entrepreneurial Inadequacy in Kenya
}

\author{
X. N. Iraki \\ University of Nairobi
}

\begin{abstract}
There is belief that Kenyans who pursue higher degrees, specifically PhD are not entrepreneurial and use qualifications to mask their "entrepreneurial inadequacies". This paper investigates this belief by using empirical data collected from a sample of PhD students in one Kenyan university. The study analyzes the entrepreneurial activities of the sample based on gender, age, undergraduate specialization, exposure (proxied by travelling abroad), professional orientation and social mobility (proxied by their current position in the organizations they work). The study is cross-sectional, and finds that most students are pursuing a PhD not because of "entrepreneurial inadequacy" but have capacity in terms of time, energy and some money. Self actualization and creating a "hedge" against unemployment and retirement are other reasons driving Kenyans, whose average age is about 40 years into classroom. The amount of money they make from "side hustles" leaves no doubt that they did not get into entrepreneurship by chance or desperation. The study further debunks the myth that entrepreneurship is for "failures."
\end{abstract}

Key words: entrepreneurship, academia, Kenya, hustle, $\mathrm{PhD}$

\section{INTRODUCTION: WHY PHD?}

The pursuit of higher education particularly $\mathrm{PhD}$ is driven by many factors among them prestige, love for knowledge and research, higher earnings, unemployment, and requirements for employment from regulators and universities. The Economist (2010) notes that "In most countries a PhD is a basic requirement for a career in academia. It is an introduction to the world of independent research" Others argue it's for those who feel inadequate to pursue other opportunities. This paper seeks to investigate what drives students to PhD in one Kenyan University and if $\mathrm{PhD}$ attracts those who feel in adequate in entrepreneurship and shy away from pursuing opportunities elsewhere.

The paper addresses the following questions; is higher education a "hiding place" for those who want to avoid reality of entrepreneurship \& business? The study posits that by looking at characteristics of those who pursue higher education, we can "measure entrepreneur inadequacy." In Kenya, the population of PhD students has gone up in the past few years. Omanga (2017) notes that "Kenya produces only 230 doctorates annually against a target of 1,000 PhDs. The table below shows the number of PhD in a selected number of countries. Except South Africa, the rest of Africa is lagging behind. By finding why students pursue PhD in Kenya and their characteristics, we could explain the low numbers. 
Figure 1: PhD graduates in selected countries

\section{The Countries With The Most Doctoral Graduates \\ Number of doctoral graduates (all fields) in 2014}

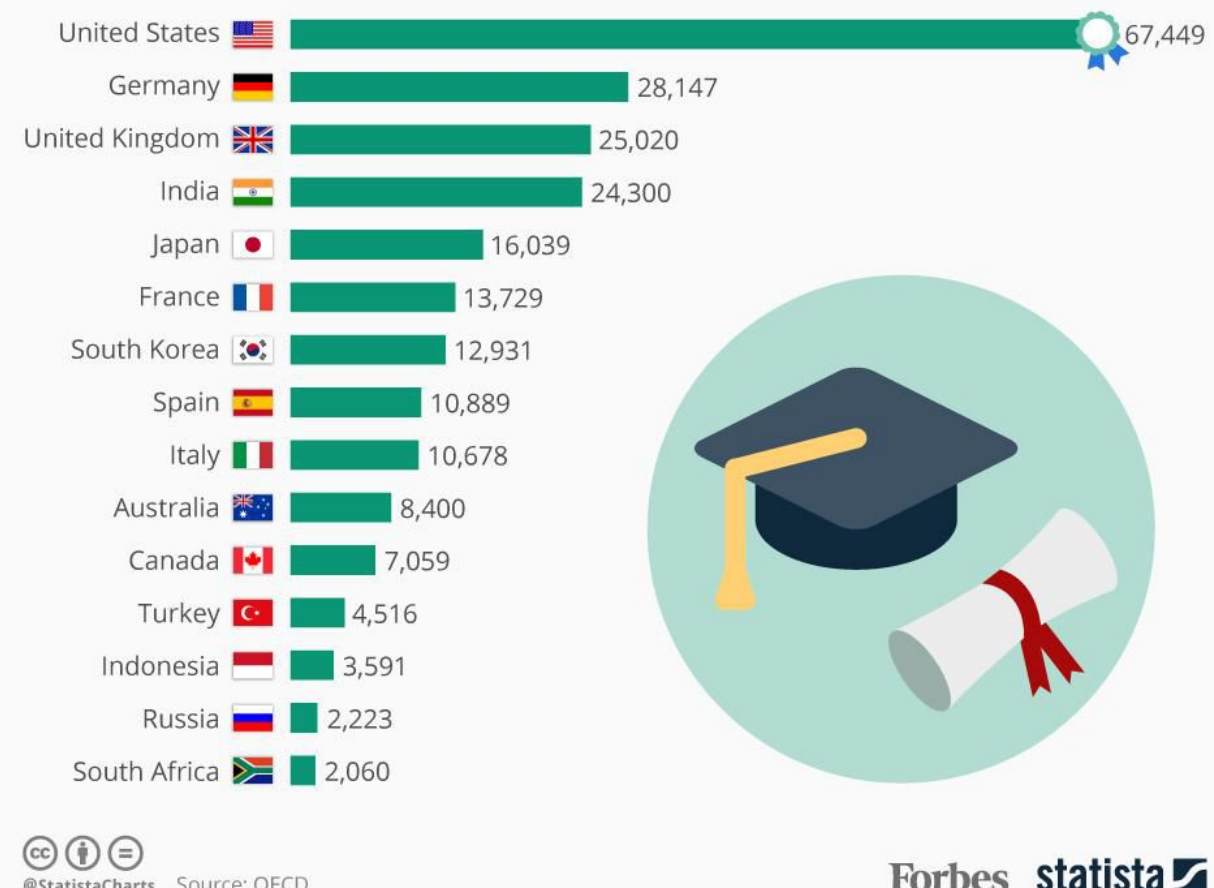

\section{METHODOLOGY}

A sample of $51 \mathrm{PhD}$ was surveyed in Jan-April 2017 semester. They were requested to fill a questionnaire in class. To ensure objectivity, they were requested to be anonymous, not to disclose their names or admission numbers. The questionnaire was paper format and took about 10 minutes to fill up. The students were not warned in advance which increased objectivity. Women were 27.5 percent of the sample, but the reasons were not analysed based on gender.

\section{RESULTS}

The key reason for pursuing a PhD was get into consulting given by about $16 \%$ of the respondents. Only 4 per cent gave entrepreneurship as the reason. Others reasons were given by 2 percent or less. Clearly, the reason for taking a PhD seems very personal and varied. Tarvid (2014) noted that PhD are motivated by labour markets, acquisition of research skills, intrinsic interest, personal development, and the joy of study, personal fulfilment and career change. Clearly, career change into consulting seems the key motivator.

The paper also sorts to find out how long the PhD students took in months to get their first job. The mean was 1.62 months. That is almost after leaving school. That has changed now in Kenya with graduates going for years without a job. Could this "lack of joblessness" be driving them to consultancy, thinking that grass is greener on the other side of the fence? With an average of 39years, it's possible they have reached the top of their career and want a break. 55 per cent got their jobs through an interview (competitively) which supports the fact that they long for a change. The mean number of time they have changed jobs is about 2 times (rounded downwards). This consistency might be another source of boredom and search for change. Interestingly, the sample was divided 50-50 in terms of those who work for public versus private sector. 
Figure 2: The time it took in months to get a job

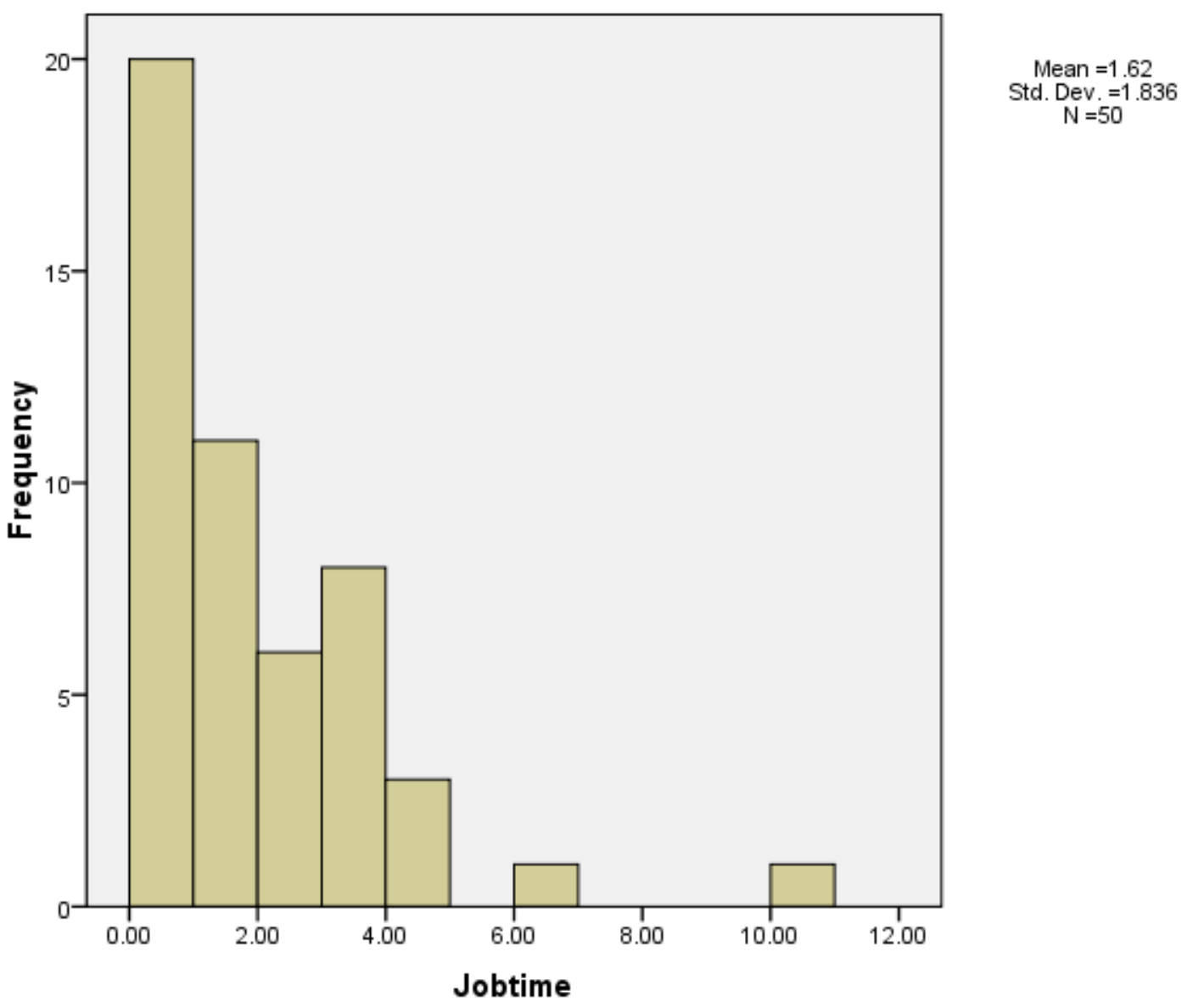

Figure3: Number of times one has changed jobs

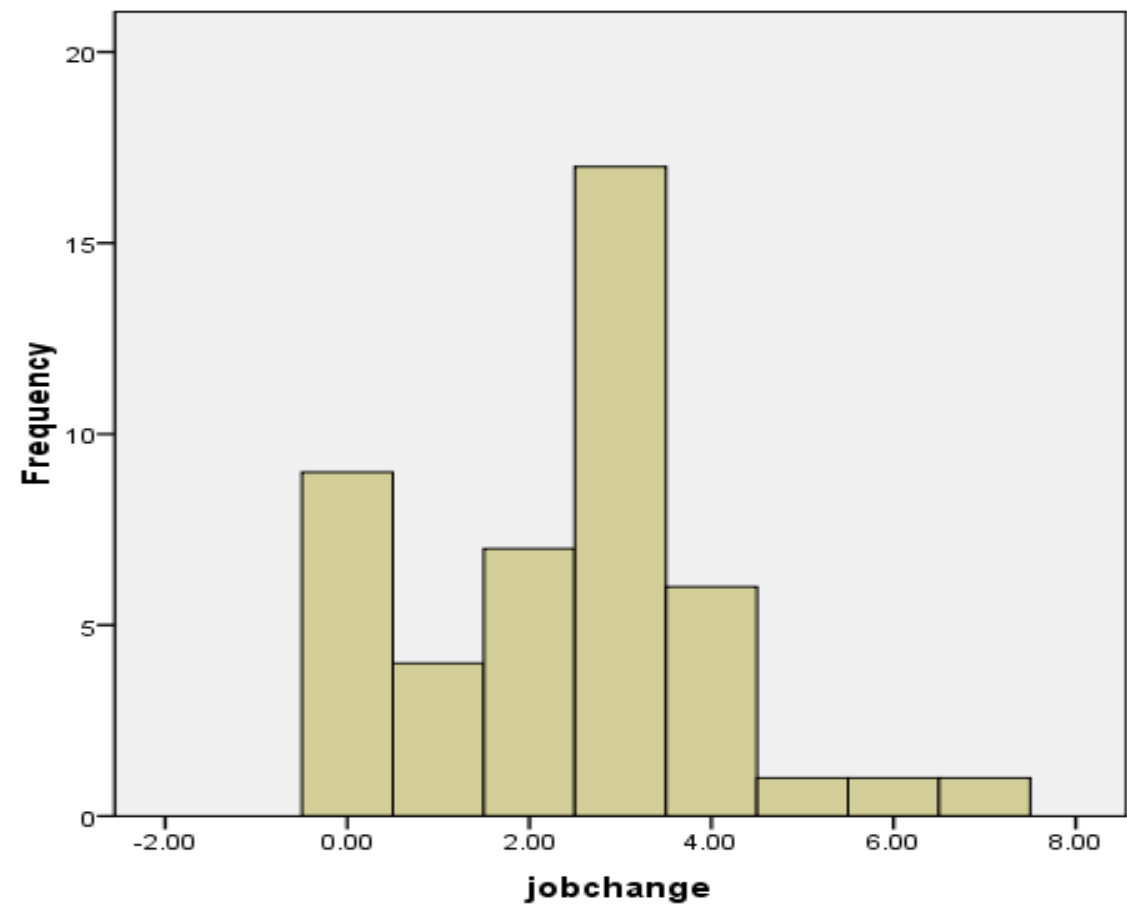

Mean $=2.41$
Std. Dev. $=1.654$ $\mathrm{N}=46$

Beyond sticking to one job, the researcher speculated that the entrepreneurial orientation of the PhD students could be driven by exposure which stirs innovation. This is proxied by travelling abroad. About 75 percent had travelled abroad. Could this have exposed them to new ideas and made them shift to entrepreneurship? Immigrants make great entrepreneurs 
because of getting out of the comfort zone. Vandor and Franke (2016) notes, "In the U.S., immigrants are almost twice as likely to become entrepreneurs as native-born U.S. citizens. Immigrants represent $27.5 \%$ of the countries' entrepreneurs but only around $13 \%$ of the population."

Figure 4: Evidence of travelling abroad

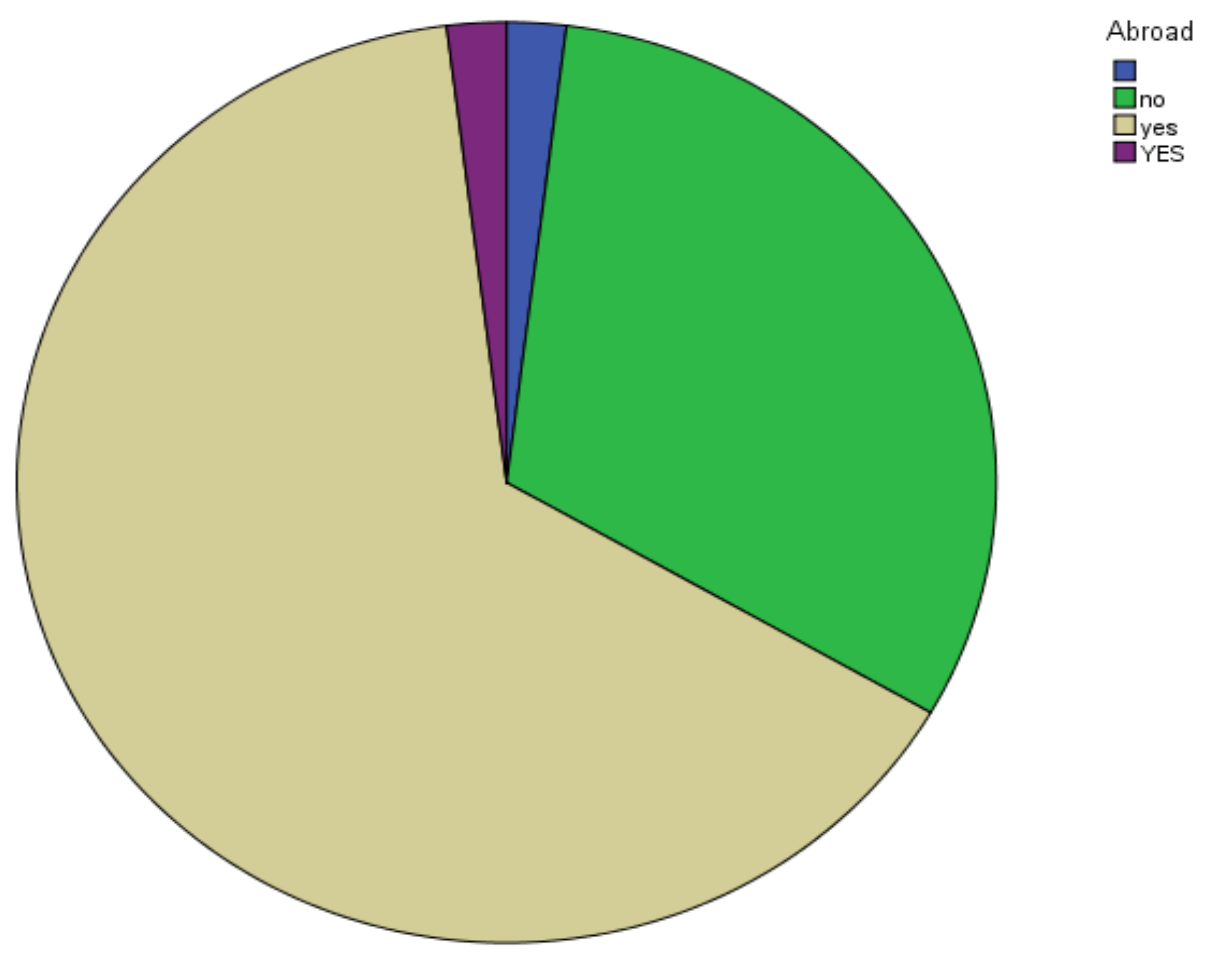

To analyze the group farther, $76.5 \%$ are married and $51 \%$ from same tribe, 49 per cent have cross cultural marriages, which can be a proxy for cross cultural experience. $30 \%$ of the couples met in school/college. The mean marriage age is 29.1 years. The mean for females is 28 years, for men 30.14 . With the average age being 39 , it means they have been married for 10 years, enough to be mentally settled to look for new challenges including entrepreneurship. Mid-life crisis could also be motivating them to pursue new objectives in life like entrepreneurship and PhD itself.

The study assumed that the farther you marry the more risk you are willing to take and by extension, the more entrepreneurial you are. Mean distance was $201 \mathrm{~km}$. That is about a quarter of Kenyan width from East to West. Considering that most of those married met in college, it can be concluded that they went to school and marriage followed. Since they had the option of marrying back in their village, but choose not to, we can suggest that distance is a sign of entrepreneurship. The mean number of children is about 2(maximum was 4) which gives them father freedom to pursue their interests. 37.5 percent were members of a savings group (chama). Is that where they got the money to invest? Could the groups(chamas) be motivating members to be entrepreneurs? The other indicator of mental settlement and readiness to take risk is that 49 percent owned a house at age 39 , which is lower than the national average at house ownership (45 years). The other indictor of social economic class of PhD students was the engine capacity of their car which had a mean of $2.055 \mathrm{cc}$. The average engine capacity is $1500 \mathrm{cc}$. Interestingly, among those who had a side business, about 50 per cent had a business-related undergraduate major. It seems going to business schools motivates you to be an entrepreneur. Only two went to prestigious national schools. 
Figure 5: The distance one married from (in km)

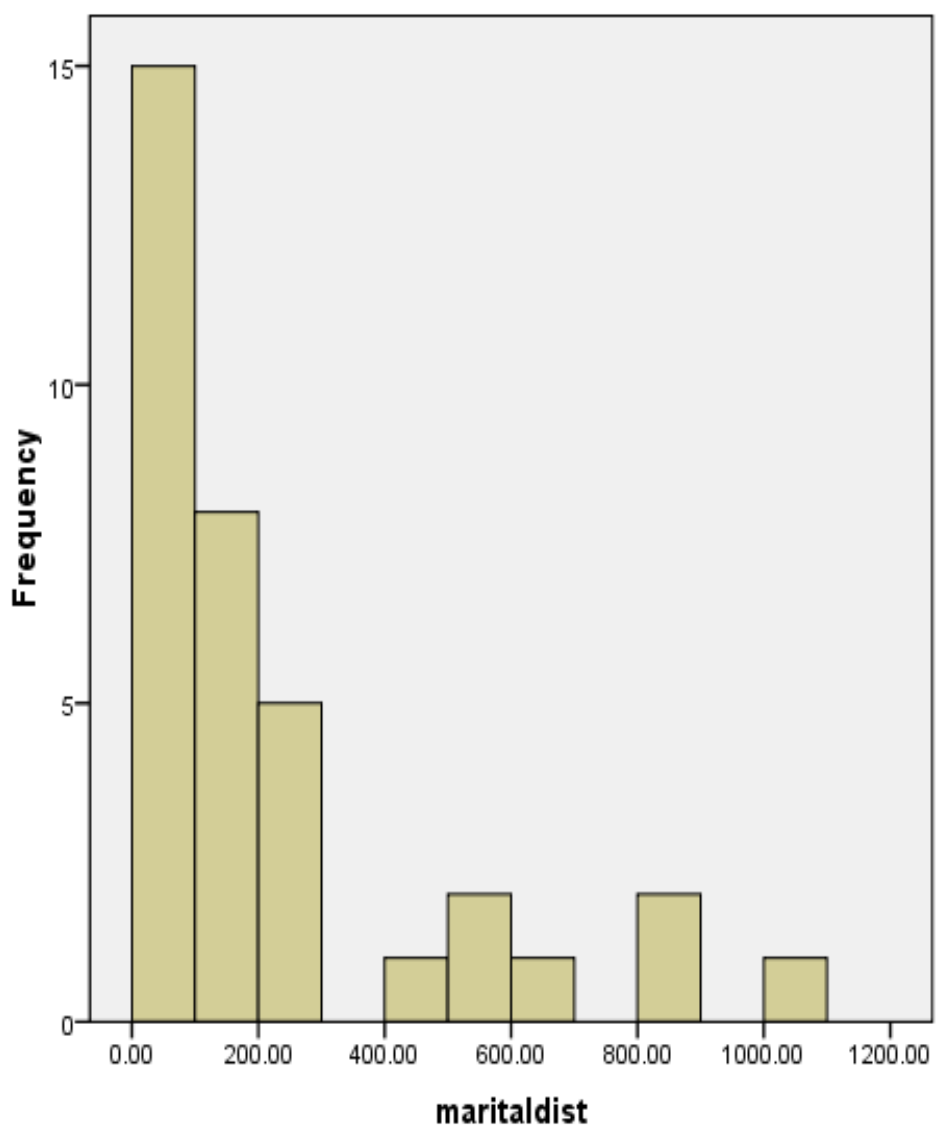

Std. Dev $=255.462$

$\begin{aligned} \text { Std. Dev. } & =255.462 \\ N & =35\end{aligned}$

Table 1: Car Engine Size in cc

Descriptive Statistics

\begin{tabular}{|l|c|c|c|c|c|}
\hline & $\mathrm{N}$ & Minimum & Maximum & Mean & $\begin{array}{c}\text { Std. } \\
\text { Deviation }\end{array}$ \\
\hline Cc & 36 & 1400.0 & 4000.0 & 2055.55 & 532.081 \\
$\begin{array}{l}\text { Valid N } \\
\text { (listwise) }\end{array}$ & 36 & & & & \\
\hline
\end{tabular}

Are PhD Students dreamer in entrepreneurship or they are in it? 74.5 percent had another business beyond their jobs (called side hustle). The average age of the hustle was six years; they stated it around age 33. There no dominant side hustle again confirming that PhD students were a very varied group. On satisfaction with their lives, the average score was 2.9 out of 5, a score of 58 percent. Could dissatisfaction with own lives be why they are entrepreneuring? What was surprising was that the hustle income (entrepreneur's income) was 54 percent of their income from full employment job and 35 percent of the total. The shift to informal sector for PhD students follows national patterns as reported by Kenya national bureau of statistics (2016) where 83 percent of employment is in the informal sector. Even PhD students are in it. 
Table 2: Income from employment vs. entrepreneurship

\begin{tabular}{|l|c|c|c|c|c|}
\hline & $\mathrm{N}$ & Minimum & Maximum & Mean & $\begin{array}{c}\text { Std. } \\
\text { Deviation }\end{array}$ \\
\hline $\begin{array}{l}\text { income from } \\
\text { Job (kSh) }\end{array}$ & 48 & 30000.00 & 1200000.0 & 250510.520 & $2.66627 \mathrm{E} 5$ \\
$\begin{array}{l}\text { Hustle income } \\
\text { (ksh) }\end{array}$ & 36 & 4000.00 & 1000000.0 & 136166.666 & $2.22515 \mathrm{E} 5$ \\
$\begin{array}{l}\text { Valid N } \\
\text { (listwise) }\end{array}$ & 36 & & & & \\
\hline
\end{tabular}

Finally, a simple regression model was used to investigate what drives PhD students to entrepreneurship. The entrepreneurship is proxied by the income from side hustle. The other drivers are satisfaction (as self reported), marital distance (proxy for risk taking), time they took to get the job (proxy for comfort), and engine capacity for your income.

$\mathrm{F}$ had a $\mathrm{p}$ value $=0.034$, an indicator that the regression model was a good fit. The value RSquared was 0.461 , only 46 percent of the entrepreneurial income is explained by the four variables. That is quite significant. The negative sign for comfort is surprising, though not significant. Comfort is an enemy of entrepreneurship even for PhD Students. Time to get the job was also negative. It seems the soon you get the job after school, the less entrepreneurial you become. It makes you comfortable. Only the engine size can predict the amount of money you can make from side hustle. It seems money begets money as capitalism says.

Table 3: Regression output

\begin{tabular}{|c|c|c|c|c|c|c|}
\hline \multirow{2}{*}{\multicolumn{2}{|c|}{ Model }} & \multicolumn{2}{|c|}{$\begin{array}{l}\text { Unstandardized } \\
\text { Coefficients }\end{array}$} & \multirow{2}{*}{$\begin{array}{c}\begin{array}{c}\text { Standardized } \\
\text { Coefficients }\end{array} \\
\text { Beta }\end{array}$} & \multirow[b]{2}{*}{$\mathbf{t}$} & \multirow[b]{2}{*}{ Sig. } \\
\hline & & B & Std. Error & & & \\
\hline \multirow[t]{5}{*}{1} & (Constant) & -174603.7 & 287388.858 & & -.608 & .552 \\
\hline & Satisfaction & -30344.448 & 54159.277 & -.111 & -.560 & .583 \\
\hline & Time to get Job & -54984.574 & 43794.379 & -.253 & -1.256 & .227 \\
\hline & Car CC & 240.007 & 92.825 & .514 & 2.586 & .020 \\
\hline & Maritaldistance & 177.825 & 190.349 & .184 & 0.934 & .364 \\
\hline
\end{tabular}

a. Dependent Variable: Hustle income

\section{CONCLUSION}

From the above analysis, PhD entrepreneurs are not that different from other entrepreneurs. Entrepreneurship inadequacy among the PhD students is a myth. They go to entrepreneurship to make more money not because they have no money. It's a myth that well educated people have no interest in entrepreneurship. On 2 out of 51 students mentioned self actualization as 
one of the motivations behind going for a PhD. Could that explain why their side hustles were typical? The fact that 2 out of 51 went to prestigious national schools might explain to some extent the "typicalness" of their entrepreneurial orientation. Further 64.5 per cent grew up in the rural areas. From this analysis, we can conclude that entrepreneurs and academics are not strange bedfellows. They are great friends. We need more research across disciplines and countries. The economic circumstances under which they became entrepreneurs e.g. boom or bust also need to be investigated.

\section{References}

The Economist (2010). Why doing a PhD is often a waste of time.

Omanga, D (2017), Why Kenya ranks so lowly in doctoral studies among peers in the region, The Standard, June 9th 2017.

https://www.standardmedia.co.ke/article/2001242872/why-kenya-ranks-so-lowly-in-doctoral-studies-amongpeers-in-the-region, retrieved on 22 October 2018

South African Journal of Science (2010), How could South Africa produce more PhDs? http://dx.doi.org/10.4102/sajs.v106i11/12.522, retrieved on October 22, 2018

Tarvid, A (2014), Motivation to Study for PhD Degree: Case of Latvia, International Conference On Applied Economics (ICOAE)

Vandor, V \& Franke, B (2016), Why Are Immigrants More Entrepreneurial? Harvard Business Review. 